\title{
NOTE
}

\section{Composition of the Essential Oil of Allium neapolitanum Cirillo Growing Wild in Sicily and its Activity on Microorganisms Affecting Historical Art Crafts}

\author{
Simona Casiglia', Maurizio Bruno ${ }^{1, *}$, Federica Senatore ${ }^{2}$ and Felice Senatore ${ }^{3}$ \\ ${ }^{1}$ Department STEBICEF, University of Palermo, Viale delle Scienze, Parco d'Orleans II - 90128 Palermo, ITALY \\ ${ }^{2}$ Department of Pharmacy, University of Salerno, Via G. Paolo II, 132 - 84084 Fisciano (SA), ITALY \\ ${ }^{3}$ Department of Pharmacy, University of Naples "Federico II", Via D. Montesano, 49 - 80131 Naples, ITALY
}

\begin{abstract}
Essential oil of the aerial parts of Allium neapolitanum Cirillo collected in Sicily were analyzed by gas-chromatography-flame-ionization detection and gas-chromatography-mass spectrometry. Nineteen compounds were identified in the oil and the main components were found to be $(E)$-chrysanthenyl acetate (28.1\%), (Z)-chrysanthenyl acetate $(\mathbf{2 3 . 8 \%}),(E)$ - $\beta$-farnesene $(9.6 \%)$, dimethyl trisulfide $(9.6 \%)$, camphor (7.4\%), methyl allyl disulfide (6.8\%) and 1-methyl-3-allyl trisulfide (5.8\%). The essential oil showed good antimicrobial activity against 11 strains of test microorganisms, including several species infesting historical material.
\end{abstract}

Key words: Allium neapolitanum, essential oil, (E)-chrysanthenyl acetate, $(Z)$-chrysanthenyl acetate, antimicrobial activity

\section{INTRODUCTION}

The genus Allium is the largest genus of the family Alliaceae and comprises more than 700 species distributed all over Europe, North America, Northern Africa and Asia, each differing in taste, form and colour, but close in biochemical, phytochemicals and nutraceutical content ${ }^{1)}$. The Allium genus is rich of flavonoids, saponins, sapogenins and volatile sulphur compounds and their characteristic organoleptic properties derive from the presence of nonvolatile flavour precursors, alk (en)yl-L-cysteine sulfoxides $^{2}$. Many sulphur compounds found in Allium species are responsible for several biological properties such as antimicrobial $^{3)}$, antiprotozoal, antioxidant, antihypertensive, hypolipidaemic, hepatoprotective and antithrombotic activities $^{4)}$.

Allium neapolitanum Cirillo is a perennial bulbous plant, native to the Mediterranean Region and the Mid-East from Spain to Pakistan ${ }^{5)}$. In Sicily it is a non common plant, growing below $1000 \mathrm{~m} \mathrm{~s} / \mathrm{l}$ in pastures, cultivated grounds (vineyards and olive-grove) and dry, open habitats ${ }^{6}$.

Previous phytochemical studies on the composition of $A$. neapolitanum led to the isolation of thirteen flavonoid glycosides, based on kaempferol, quercetin and isorhamne- $\operatorname{tin}^{7)}$ and two canthin-6-one alkaloids with antibacterial activity $^{8)}$. Furthermore, the antioxidative properties of the aqueous extracts of bulbs, bulblets, leaves and flowers of $A$. neapolitanum were investigated showing a good antiradical power ${ }^{9}$. It was also showed that the good antihypertensive effects of the aqueous extract of bulbs of $A$. neapolitanum could to be associated to interactions with adrenergic receptor $\beta_{2}$ antagonist, involved in blood pressure regulation ${ }^{10}$. Finally, the chloroform extract of this species was found to have antimicrobial activity on several bacteria and on C. albicans, in some cases better than streptomycin sulphate and nystatin, respectively, used as standard antibiotics ${ }^{11}$. On the hand no report has been published on the composition of the essential oil of this species.

Several heterotrophic microorganisms (bacteria and fungi) have the ability to interact with historical organic materials such as textile, leather, paper, paintings, wood, papyri, incunabula and books, all consisting essentially of natural fibres. Microbial growth causes loss of strength and elongation, oxidation state, discoloration, changes in appearance, degree of polymerization and breakdown of molecular structure. Species of genus Bacillus, frequent in

* Correspondence to: Maurizio Bruno, Department STEBICEF, University of Palermo, Viale delle Scienze, Parco d'Orleans II - 90128 Palermo, ITALY

E-mail: maurizio.bruno@unipa.it

Accepted September 28, 2015 (received for review July 31, 2015)

Journal of Oleo Science ISSN 1345-8957 print / ISSN 1347-3352 online

http://www.jstage.jst.go.jp/browse/jos/ http://mc.manusriptcentral.com/jjocs 
archives, libraries and on museum cellulosic objects can cause deep deteriorations of the items but the most dangerous microorganisms both for cellulose fibers and fibers of animal origin (wool, silk) belong to some genera of fungi: Chaetomium, Myrothecium, Trichoderma, Fusarium, Penicillium and Aspergillus.

Also the surfaces of stone monuments can be altered by fungal activity via hyphal penetration through the porous stone matrix and by the production of organic acids and pigments ${ }^{12)}$. The growing interest on natural products that can be used as an alternative to synthetic chemicals in order to prevent and reduce the dangerous effects of microorganisms on historical artifacts ${ }^{13-15)}$ prompted us to investigate on the chemical composition and anti-microbial properties against several microorganism, including Bacillus subtilis, Fusarium oxysporum and Aspergillus niger, species infesting historical material ${ }^{13)}$, of the essential oil from aerial parts of $A$. neapolitanum, growing wild in Sicily.

\section{MATERIALS AND METHODS}

\subsection{Plant material}

Aerial parts of Allium neapolitanum were collected 2 km west of Portella della Ginestra, Piana degli Albanesi,

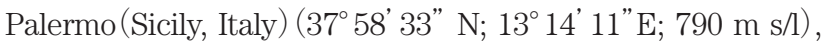
at the end of May 2014, from plants at the full flowering stage. Typical specimens (PAL 14/84), identified by Mr. Emanuele Schimmenti, have been deposited have been deposited in the Department STEBICEF, University of Palermo, Palermo, Italy.

\subsection{Isolation of the essential oil}

The air-dried sample was ground in a Waring blender and then subjected to hydrodistillation for $3 \mathrm{~h}$ using $n$-hexane as solvent, according to the standard procedure previously described ${ }^{16)}$. The oil was dried over anhydrous sodium sulphate and then stored in sealed vials, at $-20^{\circ} \mathrm{C}$, ready for the GC and GC-MS analyses. The sample yielded $0.22 \%$ of oil $(w / w)$ (A.n.) with a typical garlic smell.

\subsection{Qualitative and quantitative analyses}

The essential oil was analyzed to determine the chemical components by GC and GC-MS as previously described and identification of constituents was made by comparison of their retention indices $\left(R_{i}\right)$ with either those of the literature or with those of authentic compounds available in our laboratories ${ }^{17)}$.

\subsection{Microbial strains}

The antimicrobial and antifungal activities of essential oil were tested against a panel which included eight bacteria species, selected as representative of the class of Gram positive and Gram negative (Table 2). The strains were grown on Tryptone Soya Agar (Oxoid, Milan, Italy) for the bacteria, Saboureaud Dextrose Agar(SDA) with chloramphenicol for yeasts and SDA for moulds. For the antimicrobial tests, Tryptone Soya broth (Oxoid, Milan, Italy) for bacteria and Sabouraud dextrose broth (SDB) for yeasts and fungal strains were used.

\subsection{Antimicrobial screening}

The antimicrobial activity was evaluated, as previously reported ${ }^{14)}$, by determining the minimum inhibitory concentration (MIC) and the minimum microbicidal concentration (MMC), which includes minimum bactericidal (MBC) and minimum fungicidal concentrations (MFC), using the broth dilution method ${ }^{18)}$.

\section{RESULTS AND DISCUSSION}

\subsection{Chemical composition of the essential oil}

Hydrodistillation of the aerial parts of Allium neapolitanum gave a yellow oil (A.n.). Overall, nineteen compounds were identified in the oil, representing $96.8 \%$ of the total components. The components are listed in Table 1 according to their retention indices on a HP 5MS column and are classified on the basis of their chemical structures into five classes.

The main class was represented by oxygenated monoterpenes with $(E)$-chrysanthenyl acetate $(28.1 \%),(Z)$-chrysanthenyl acetate $(23.8 \%)$ and camphor $(7.4 \%)$ as main compounds. Among the sulphur-containing compounds (23.6\%), dimethyl trisulfide (9.6\%), methyl allyl disulfide $(6.8 \%)$ and 1-methyl-3-allyl trisulfide (5.8\%) were the most abundant products. It is worthy of mention the good quantity of $(E)$ - $\beta$-farnesene $(9.6 \%)$, the only sesquiterpene hydrocarbon detected in the oil.

The comparison with the compositions of the essential oil from aerial parts of Allium sp. studied so far shows some interesting points. In fact, it is noteworthy that the percentage of sulphur-containing compounds varies drastically: A. ampeloprasum ${ }^{19)}$ and $A$. nigrum $^{20)}$ are devoid of these compounds whereas other species such as $A$. cepa $(100 \%)^{21)}$, A. fistulosum $(95.8 \%)^{22)}$, A. chinense from Cuba $(94.0 \%)^{23)}$ and A. tuberosum from China $(92.9 \%)^{24)}$ are extremely rich of this class of compounds. The oil of Allium neapolitanum shows a moderate content of sulphur-containing compounds $(23.6 \%)$ and it has to be pointed out that $(E)$-chrysanthenyl acetate, $(Z)$-chrysanthenyl acetate and $(E)$ - $\beta$-farnesene have never been identified in significant amount in any Allium oil. Among the oxygenated monoterpenes present in A. neapolitanum only camphor has been identified in good amount (13.4\%) in $A$. roseum var. odoratissimum from Tunisia ${ }^{25)}$. 
Table 1 Percent composition of the essential oils of Allium neapolitanum Cirillo (Alliaceae).

\begin{tabular}{|c|c|c|c|c|}
\hline $\mathrm{K}_{\mathrm{i}}^{\mathrm{a}}$ & $\mathrm{K}_{\mathrm{i}}^{\mathrm{b}}$ & Component & A.n. & Ident. \\
\hline 1145 & 1532 & Camphor & 7.4 & $1,2,3$ \\
\hline 1235 & 1583 & (E)-Chrysanthenyl acetate $* *$ & 28.1 & 1,2 \\
\hline 1257 & 1585 & (Z)-Chrysanthenyl acetate ** & 23.8 & 1,2 \\
\hline \multirow[t]{2}{*}{1284} & 1597 & Bornyl acetate & 1.6 & $1,2,3$ \\
\hline & & Oxygenated monoterpenes & 60.9 & \\
\hline \multirow[t]{2}{*}{1452} & 1672 & $(E)$ - $\beta$-Farnesene & 9.6 & 1,2 \\
\hline & & Sesquiterpene hydrocarbons & 9.6 & \\
\hline 908 & & 2,5-Dimethylthiophene & $\mathrm{t}^{\mathrm{d}}$ & 1,2 \\
\hline 917 & 1308 & Methyl allyl disulfide ; Methyl 2-propenyl disulfide & 6.8 & 1,2 \\
\hline 926 & 2285 & Diethyl disulfide & $t^{d}$ & 1,2 \\
\hline 952 & 1145 & Methyl 1-propenyl disulfide & 0.9 & 1,2 \\
\hline 973 & 1403 & Dimethyl trisulfide; DMTS & 9.6 & 1,2 \\
\hline 1083 & 1434 & Di-2-propenyl disulfide; Diallyl disulfide & 0.2 & 1,2 \\
\hline 1087 & 1330 & Dipropyl disulfide & 0.2 & 1,2 \\
\hline 1096 & 1436 & Dipropenyl disulfide & 0.1 & 1,2 \\
\hline \multirow[t]{2}{*}{1137} & 1506 & 1-Methyl-3-allyl trisulfide & 5.8 & 1,2 \\
\hline & & Sulphur-containing compounds & 23.6 & \\
\hline \multirow[t]{2}{*}{802} & 1168 & Hexanal; Caproaldehyde & 0.3 & $1,2,3$ \\
\hline & & Carbonylic compounds & 0.3 & \\
\hline 2100 & 2100 & Heneicosane & 0.1 & $1,2,3$ \\
\hline 2300 & 2300 & Tricosane & 0.4 & $1,2,3$ \\
\hline 2500 & 2500 & Pentacosane & 0.7 & $1,2,3$ \\
\hline \multirow[t]{3}{*}{2700} & 2700 & Heptacosane & 1.2 & $1,2,3$ \\
\hline & & Hydrocarbons & 2.4 & $1,2,3$ \\
\hline & & TOTAL & 96.8 & \\
\hline
\end{tabular}

${ }^{\mathrm{a}}$ : HP-5 MS column; ${ }^{\mathrm{b}}$ : HP Innowax column ${ }^{\mathrm{c}}$ : 1 , retention index, 2: mass spectrum, 3: co-injection with authentic compound; ${ }^{\text {d: }}$ t: trace, $<0.05 \%$; $* *$ : irregular terpene.

\subsection{Biological activity}

The antimicrobial and antifungal activities of essential oil were tested against a panel which included eight bacteria species, selected as representative of the class of Gram positive and Gram negative, one yeast and two moulds. The oil shows a good activity especially against Bacillus subtilis, Staphylococcus aureus, Fusarium oxysporum and Aspergillus niger (Table 2). Although for the two main compounds of the oil, $(E)$-chrysanthenyl acetate and $(Z)$-chrysanthenyl acetate, no biological properties have been reported, the good antimicrobial activity of the oil can be attributed to the presence of camphor, dimethyl trisulfide, methyl allyl disulfide and 1-methyl-3-allyl trisulfide, compounds already proved to be very active ${ }^{26-29)}$.

Previous studies on the structure-activity relationship of garlic metabolites showed antimicrobial activity for allyldisulfide, but not for allylsulfide ${ }^{30)}$ suggesting that the disul- fide bond may be important for the antimicrobial effect. Furthermore, it has been reported ${ }^{27)}$ that the presence of the trisulfide bond, or of an extra sulphur in the molecule, may reduce the biological properties of the allylsulfide constituents of garlic oils. Consequently, the high antimicrobial activity of $A$. neapolitanum essential oil can be attributed to the presence both of allyldisulfides and camphor; the antibacterial and antifungal properties of the last one have been largely demonstred ${ }^{26,31-33)}$.

The antimicrobial activity of other essential oils from Allium species have been also demonstrated. The essential oils of different Allium nigrum L. organs ${ }^{20)}$ and Allium roseum var. grandiflorum subvar. typicum Regel. ${ }^{34)}$, both collected in Tunisia, exhibited antimicrobial activity, especially against Enterococcus faecalis and Staphylococcus aureus $^{20)}$ and antifungal growth effect on Fusarium solani f. sp. cucurbitae and Botrytis cinerea ${ }^{34)}$. The es- 
Table 2 MIC $(\mu \mathrm{g} / \mathrm{mL})$ and MMC* $(\mu \mathrm{g} / \mathrm{mL})$ of essential oil from Allium neapolitanum.

\begin{tabular}{|c|c|c|c|c|}
\hline Strain & A.n. & $\mathrm{Ch}$ & $\mathrm{Am}$ & $\mathrm{Ke}$ \\
\hline \multicolumn{5}{|l|}{ Bacillus subtilis } \\
\hline ATCC 6633 & $12.5(25)$ & 12.5 & NT & NT \\
\hline \multicolumn{5}{|c|}{ Staphylococcus aureus } \\
\hline ATCC 25923 & $25(50)$ & 25 & NT & NT \\
\hline \multicolumn{5}{|c|}{ Staphylococcus epidermidis } \\
\hline ATCC 12228 & $12.5(25)$ & 3.12 & NT & NT \\
\hline \multicolumn{5}{|c|}{ Streptococcus faecalis } \\
\hline ATCC 29212 & 50 & 25 & NT & NT \\
\hline \multicolumn{5}{|l|}{ Escherichia coli } \\
\hline ATCC 25922 & $25(50)$ & 12.5 & NT & NT \\
\hline \multicolumn{5}{|c|}{ Klebsiella pneumoniae } \\
\hline ATCC 10031 & $50(100)$ & 50 & NT & NT \\
\hline \multicolumn{5}{|l|}{ Proteus vulgaris } \\
\hline ATCC 13315 & 100 & 25 & NT & NT \\
\hline \multicolumn{5}{|c|}{ Pseudomonas aeuriginosa } \\
\hline ATCC 27853 & $100(>100)$ & 100 & NT & NT \\
\hline \multicolumn{5}{|l|}{ Candida albicans } \\
\hline ATCC 10231 & 50 & NT & 1.56 & NT \\
\hline \multicolumn{5}{|c|}{ Fusarium oxysporum } \\
\hline ATCC 695 & $6.25(12.5)$ & NT & NT & 3.12 \\
\hline \multicolumn{5}{|l|}{ Aspergillus niger } \\
\hline ATCC 16401 & 6.25 & NT & NT & 3.12 \\
\hline
\end{tabular}

* MBC are reported in brackets when different from MIC; NT: not tested; Ch: Chloramphenicol; Am: Amphotericin B; Ke: Ketoconazole.

sential oil of the flowers of A. roseum var. odoratissimum from Tunisia showed good activity against Micrococcus luteus, Staphylococcus epidermidis and S. aureus ${ }^{25)}$. Also the oil of the flowers of $A$. rotundum from Iran indicates a good activity against Proteus mirabilis, Enterobacter cloacae, Klebsiella pneumoniae, Staphylococcus aureus and Bacillus subtilis ${ }^{35)}$. A good activity against Gram positive bacteria (Staphylococcus aureus, Enterococcus faecalis) was reported for the essential oil of $A$. schoenoprasum, collected in Turkey ${ }^{36)}$. On the other hand the oil obtained from the flowers of $A$. sphaerocephalon subsp. sphaerocephalon was proved to be quite active against Pseudomonas aeruginosa and Aspergillus niger $^{37)}$. Shallot (Allium ascalonicum L.) oil was studied for its major diallyl sulfide content and its antimicrobial activity against food-borne pathogenic bacteria including $B a$ cillus cereus, Campylobacter jejuni, Escherichia coli O157:H7, Listeria monocytgenes, Salmonella enterica, Staphylococcus aureus, and Vibrio cholerae. Among them, E. coli O157:H7 and B. cereus were the most and the least sensitive strains, respectively. The oil had a bactericidal effect on C. jejuni, E. coli O157:H7, L. monocytgenes, $S$. aureus and $V$. cholerae but had a bacteriostatic effect on B. cereus and S. enterica ${ }^{38)}$.

The good antimicrobial activity detected for the essential oil of A. neapolitanum especially against Bacillus subtilis, Staphylococcus aureus, Fusarium oxysporum and Aspergillus niger, species infesting archives, libraries and historical cellulosic textiles objects quite frequently, makes this plant interesting for possible applications in the protection and disinfestation of museum objects.

\section{ACKNOWLEDGMENT}

The GC and GC-MS spectra were performed at the Department of Pharmacy, University of Naples "Federico II". The assistance of the staff was gratefully appreciated. 


\section{References}

1) Hirschegger, P.; Jakse, J.; Trontelj, P.; Bohanec, B. Origins of Allium ampeloprasum horticultural groups and a molecular phylogeny of the section Allium (Allium: Alliaceae). Mol. Phylogenet. Evol. 54, 488-497 (2010).

2) Block, A. The organosulfur chemistry of the genus $A l$ lium: implications for the organic chemistry of sulfur. Angew. Chem. Int. Ed. Engl. 31, 1135-1178(1992).

3) Casella, S.; Leonardi, M.; Melai, B.; Fratini, F.; Pistelli, L. The role of diallyl sulfides and dipropyl sulfides in the in vitro antimicrobial activity of the essential oil of garlic, Allium sativum L., and leek, Allium porrum L. [Comparative study]. Phytother. Res. 27, 380-383 (2013).

4) Tapiero, H.; Townsend, D.; Tew, K. Organosulfur compounds from Alliaceae in the prevention of human pathologies. Biomed. Pharmacother. 58, 183-193 (2004).

5) http://apps.kew.org/ Kew Botanical Gardens, World Checklist of Selected Plant Families.

6) Giardina, G.; Raimondo, F. M.; Spadaro, V. A catalogue of plants growing in Sicily. Bocconea 20, 5-583 (2007).

7) Carotenuto, A.; Fattorusso, E.; Lanzotti, V.; Magno, S.; De Feo, V.; Cicala, C. The flavonoids of Allium neapolitanum. Phytochemistry 44, 949-957 (1997).

8) O’Donnell, G.; Gibbons, S. Antibacterial activity of two canthin-6-one alkaloids from Allium neapolitanum. Phytother. Res. 21, 653-657(2007).

9) Nencini, C.; Cavallo, F.; Capasso, A.; Franchi, G. G.; Giorgi, G.; Micheli, L. Evaluation of antioxidative properties of Allium species growing wild in Italy. Phytother. Res. 21, 874-878(2007).

10) Nencini, C.; Franchi, G. G.; Micheli, L. Cardiovascular receptor binding affinity of aqueous extracts from $\mathrm{Al}$ lium species. Int. J. Food Sci. Tech. 61, 433-439 (2010).

11) Dığrak, M.; Hakki Alma, M.; İlçim, A. Antibacterial and antifungal activities of Turkish medicinal plants. Pharm. Biol. 39, 346-350 (2001).

12) Stupar, M.; Grbić, M. Lj.; Džamić, A.; Unković, N.; Ristić, M.; Jelikić, A.; Vukojević, J. Antifungal activity of selected essential oils and biocide benzalkonium chloride against the fungi isolated from cultural heritage objects. S. Afr. J. Bot. 93, 118-124(2014).

13) Casiglia, S.; Bruno, M.; Senatore, F. Volatile constituents of Dianthus rupicola Biv. from Sicily: activity against microorganisms affecting cellulosic objects. Nat. Prod. Res. 28, 1739-1746 (2014).

14) Casiglia, S.; Bruno, M.; Senatore, F. Activity against microorganisms affecting cellulosic objects of the volatile constituents of Leonotis nepetaefolia from Nicaragua. Nat. Prod. Commun. 9, 1637-1639(2014).

15) Casiglia, S.; Ben Jemia, M.; Riccobono, L.; Bruno, M.;
Scandolera, E.; Senatore, F. Chemical composition of the essential oil of Moluccella spinosa L. (Lamiaceae) collected wild in Sicily and its activity on microorganisms affecting historical textiles. Nat. Prod. Res. 29, 1201-1206 (2015).

16) Ben Jemia, M.; Rouis, Z.; Maggio, A.; Venditti, A.; Bruno, M.; Senatore, F. Chemical composition and free radical scavenging activity of the essential oil of Achillea ligustica All. wild growing in Lipari (Aeolian Islands, Sicily). Nat. Prod. Commun. 8, 1629-1632 (2013).

17) Loizzo, M.; Ben Jemia, M.; Senatore, F.; Bruno, M.; Menichini, F.; Tundis, R. Chemistry and functional properties in prevention of neurodegenerative disorders of five Cistus species essential oils. Food Chem. Toxicol. 59, 586-594 (2013).

18) Barry, A. The antimicrobic susceptibility test: Principles and Practices. Lea and Febiger, Philadelphia (1976).

19) Selim, Y. A.; Sakeran, M. I. Effect of Time Distillation on Chemical Constituents and Anti-Diabetic Activity of the Essential Oil from Dark Green Parts of Egyptian Allium ampeloprasum L. J. Ess. Oil Bearing Plants 17, 838-846 (2014).

20) Rouis-Soussi, L. S.; El Ayeb-Zakhama, A.; Mahjoub, A.; Flamini, G.; Ben Jannet, H.; Harzallah-Skhiri, F. Chemical composition and antibacterial activity of essential oils from the Tunisian Allium nigrum L. EXCLI Journal 13, 526-535 (2014).

21) Ehiabhi, O. S.; Edet, U. U.; Walker, T. M.; Schmidt, J. M.; Setzer, W. N.; Ogunwande, I. A.; Essien, E.; Ekundayoet, O. Constituents of essential oils of Apium graveolens L., Allium cepa L. and Voacanga africana Staph. from Nigeria. J. Essent. Oil-Bearing Plants 9, 126-132 (2006).

22) Pino, J. A.; Rosado, A.; Fuentes, V. Volatile flavor compounds from Allium fistulosum L. J. Essent. Oil Res. 12, 553-555 (2000).

23) Pino, J.; Fuentes, V.; Correa, M. T. Volatile constituents of Chinese chive (Allium tuberosum Rottl. ex Sprengel) and rakkyo (Allium chinense G. Don). J. Agric. Food Chem. 49, 1328-1330 (2001).

24) Yang, M. Y.; Zheng, F. P.; Duan, Y.; Xie, J. C.; Huang, M. Q.; Ren, T. L.; Sun, B. G. Analysis of volatiles in wild Chinese chive flowers by solvent extraction/solventassisted flavor evaporation coupled with gas chromatography-mass spectrometry. Shipin Kexue (Beijing, China) 32, 211-216 (2011).

25) Najjaa, H.; Neffati, M.; Zouari, S.; Ammar, E. Essential oil composition and antibacterial activity of different extracts of Allium roseum L., a North African endemic species. C. R. Chimie 10, 820-826(2007).

26) Ben Hsouna, A.; Ben Halima N.; Abdelkafi, S.; Hamdi, N. Essential oil from Artemisia phaeolepis: chemical 
composition and antimicrobial activities. J. Oleo Sci. 62, 973-980 (2013).

27) Avato, P.; Tursi, F.; Vitali, C.; Miccolis, V.; Candido, V. Allylsulfide constituents of garlic volatile oil as antimicrobial agents. Phytomedicine 7, 239-243 (2000).

28) Corzo-Martmez, M.; Corzo, N.; Villamiel, M. Biological properties of onions and garlic. Trends Food Sci. Technol. 18, 609-625 (2007).

29) Mnayer, D.; Fabiano-Tixier, A. S.; Petitcolas, E.; Hamieh, T.; Nehme, N.; Ferrant, C.; Fernandez, X.; Chemat, F. Chemical composition, antibacterial and antioxidant activities of six essentials oils from the $A l$ liaceae Family." (Allium sativum), onion(Allium cepa), leek(Allium porrum), Chinese chive(Allium tuberosum), shallot(Allium ascalonicum) and chive (Allium schoenoprasum). Molecules 19, 2003420053 (2014).

30) Naganawa, R.; Iwata, N.; Ishikawa, K.; Fukuda, H.; Fujino, T.; Suzuki, A. Inhibition of microbial growth by ajoene, a sulfur-containing compound derived from garlic. Appl. Environ. Microbiol. 62, 4238-4242 (1996).

31) Mimica-Dukić, N.; Kujundžić, S.; Soković, M.; Couladis, M. Essential oil composition and antifungal activity of Foeniculum vulgare Mill. obtained by different distillation conditions. Phytother. Res. 17, 368-371(2003).

32) Kordali, S.; Cakir, A.; Mavi, A.; Kilic, H.; Yildirim A. Screening of chemical composition and antifungal and antioxidant activities of the essential oils from three Turkish Artemisia species. J. Agric. Food Chem. 53, 1408-1416 (2005).

33) Kazemi, M. Chemical composition and antimicrobial activity of essential oil of Matricaria chamomilla. Bull. Env. Pharmacol. Life Sci. 3, 148-153 (2008).

34) Rouis-Soussi, L. S.; Boughelleb-M’Hamdi, N.; El AyebZakhama, A.; Flamini, G.; Ben Jannet, H.; HarzallahSkhiri, F. Phytochemicals, antioxidant and antifungal activities of Allium roseum var. grandiflorum subvar. typicum Regel. South African J. Bot. 91, 63-70 (2014).

35) Dehpour, A. A.; Yousefian, M.; Jafary Kelarijani, S. A.; Koshmoo, M.; Mirzanegad, S.; Mahdavi, V.; Mousavi, S. E.; Shirzad, E.; Afzali, M.; Javad Bayani, M. J.; Olyaei juybari, E.; Yahyapor, M. K. Antibacterial activity and composition of essential oils of flower Allium rotundum. Adv. Environ. Biol. 6, 1020-1025 (2012).

36) Dagdelen, S.; Bilenler, T.; Durmaz, G.; Gokbulut, I.; Hayaloglu, A. A.; Karabulut, I. Volatile composition, antioxidant and antimicrobial activities of herbal plants used in the manufacture of van herby (otlu) cheese. J. Food Process. Preserv. 38, 1716-1725 (2014).

37) Lazarević, J. S.; Đorđević, A. S.; Zlatković, B. K.; Radulović, N. S.; Palić, R. M. Chemical composition and antioxidant and antimicrobial activities of essential oil of Allium sphaerocephalon L. subsp. sphaerocephalon (Liliaceae) inflorescences. J. Sci. Food Agric. 91, 322-329 (2011).

38) Rattanachaikunsopon, P.; Phumkhachorn, P. Shallot (Allium ascalonicum L.) oil: Diallyl sulfide content and antimicrobial activity against food-borne pathogenic bacteria. African J. Microbiol. Res. 3, 747-750 (2009). 